\title{
SENSITIVITY ANALYSIS FOR A HYBRID OFF-GRID PV/DG/BATT SYSTEM FOR THE ELECTRIFICATION OF RURAL COMMUNITIES
}

\author{
Pazmiño-Zapatier PEDRO ${ }^{1}$, Lata-García JUAN ${ }^{2}$ \\ ${ }^{1}$ Universidad Politécnica Salesiana, Guayaquil, Ecuador, ppazminoz@est.ups.edu.ec \\ ${ }^{2}$ Universidad Politécnica Salesiana, Grupo GIPI, Guayaquil, Ecuador, jlatag@ups.edu.ec
}

Abstract

One of the pillars for the development of isolated communities is electricity, however the implementation of conventional networks is limited as a result of the difficulties of the terrain. This paper aims to analyze the technical-economic feasibility of implementing a hybrid off-grid solar photovoltaics (PV)/diesel generator (DG)/battery (BATT) based power system for the electrification of rural communities, using a case study in Bameno, Ecuador. The simulation and optimization of the system is done using Hybrid Optimization of Multiple Energy Resources (HOMER) software. As a result, the optimal sizing is composed of $23 \mathrm{~kW} \mathrm{PV}$ modules, a DG $27 \mathrm{~kW}, 88.4 \mathrm{kWh}$ storage batteries and $9.4 \mathrm{~kW}$ converter system, obtaining a levelized cost of energy (LCOE) of $0.359 \$ / \mathrm{kWh}$. After the optimization is executed, a sensitivity analysis is performed to establish the effects of the variations of solar radiation, demand, fuel, and component costs on the system. The $\mathrm{PV} / \mathrm{DG} / \mathrm{BATT}$ system is considered the best choice for fuel prices up to $\$ 0.83$ per liter. For higher values the optimal system is the PV/BATT. It is also established that the LCOE is mostly affected by the cost of technological components, followed by variations in solar radiation and demand.

\section{INTRODUCTION}

Keywords: Renewable energy sources, Sensitivity analysis, LCOE, HOMER
Access to electricity is indispensable for health, education and good quality of life [1,2]. Despite its importance, it is estimated that globally more than 770 million people, located mainly in rural communities, do not have this supply [3]. In those populations far from urban centers, where the extension of the central grid is not technically or economically viable, diesel generators (DG) have traditionally been used to cover basic energy needs. In recent decades, due to the difficulty and high cost of transporting fuel to these areas [4] and the downward trend in prices of photovoltaic (PV) panels, wind turbines and mini-hydroelectric plants, the replacement of simple fossil fuel-based systems by renewable energy sources has raised (5). Energy storage systems (ESS) such as batteries (BATT) and fuel cells are added to compensate the natural intermittency of renewable sources, making the electrical system more continuous and reliable.

Isolated hybrid microgrid is made up by the set of elements previously mentioned. Microgrids are defined as units that operate isolated or connected to the public network and incorporate distributed generation and various loads within the framework of a delimited geographical location [5].

Multiple publications highlight the feasibility of using these systems in isolated regions.

Windt et al. [6] review microgrids in various developing countries in Asia, Africa and America, concluding that hybrid systems based on renewable energy are more appropriate and affordable for rural communities than traditional fossil fuel-based ones. Li [7] models and optimizes a system that includes PV Panels, Wind Turbine (WT) and biomass generator using Hybrid Optimization Model for Electric Renewables (HOMER), finding the system to be reliable and economically feasible for electrification on remote locations. Ur Rehman et al. [8] proposes a PV/WT/DG/BATT system for a distant village in Pakistan, finding a levelized cost of energy (LCOE) of $0.45 \$ / \mathrm{kWh}$ with renewable energy penetration of $84 \%$, which was found the most viable option.

In order to evaluate the feasibility of implementing microgrids from an economic point of view, Hossein et al. (9) proposes a model based on a method commonly used for evaluations of generation projects, through the calculation of LCOE, which represents the present net value of the unit cost of electricity over the life of the project. The LCOE is the ratio between the sum of the costs of investment, maintenance and operation, and the energy produced throughout the expected life of the project. This coefficient is compared for all available alternatives to choose the best option. Once this has been obtained, it is necessary to do simulations that verify its effectiveness under various circumstances.

\footnotetext{
(C) 2022 by the Authors. Licensee Polish Society of Technical Diagnostics (Warsow. Poland). This article is an open access article distributed under the terms and conditions of the Creative Commons Attribution (CC BY) license http://creativecommons.org/licenses/by/4.0/).
} 
This process is also known as sensitivity analysis.

Sensitivity analysis is a tool that allows the evaluation of the impact of changing an independent variable on another dependent one [10]. Sensitivity analysis can be local, in which a single variable is analyzed, or global, where multiple variables are considered.

Within microgrid implementation planning, it is usually necessary to incorporate new components, such as distributed generation and ESS, to existing resources and conditions. Due to the high costs of the elements, their proper selection is fundamental for the feasibility of the project. This represents an optimization problem that can be solved using multiple algorithms [11] and existing specialized software such as HOMER. This program optimizes the power system by simulating and executing the energy balance calculations for an entire year, hour by hour [12].

This paper analyzes the case of Bameno, a rural community located in the Amazon region of Ecuador. Bameno is isolated from the public electricity grid, and currently uses a DG and individual photovoltaic panels for the use of a few inhabitants. The feasibility of an isolated hybrid microgrid is explored by the incorporation of generation coming from available natural resources and using optimization techniques and sensitivity analysis provided by HOMER.

After reviewing the available literature, it has been found that despite the existence of multiple studies about the implementation of renewable resources in hybrid systems worldwide [13-17], very few are located in Ecuador [18]-[20], and almost none includes a sensitivity analysis. Being a developing country, with remote communities with poor electrification, but a high energy potential in their natural resources, it is necessary to carry out as many studies as possible, considering local characteristics.

The rest of the paper is organized as follows: In part II the modeling of the microgrid is performed using HOMER. Part III presents the results of optimization and sensitivity analysis. Finally, the conclusions are issued in section IV.

\section{METHODOLOGY}

\subsection{Site description}

Bameno is a remote rural community geographically located at $1^{\circ} 32^{\prime} \mathrm{S}$ and $75^{\circ} 35^{\prime} \mathrm{W}(188$ $\mathrm{m}$. above sea level). It counts with 36 houses and 139 inhabitants (21). Few of them have small individual photovoltaic panels for basic needs. A DG operates 2 times a day to supply the community water pump. The fuel is purchased at prices well above official values ( $\$ 0.42$ per liter) due to the transportation costs. It is estimated that the price of a liter of diesel in remote communities can vary between $\$ 0.79$ and $\$ 1.39$ per liter [22].

\subsection{Load profile}

The needs of households are limited to lighting, battery chargers, radios, and small appliances, having 2 peaks of demand: between 5 and 7 am when they get ready for school and work in the field, and between 6 and $8 \mathrm{pm}$ when they return to their homes. At the same time, the community drinking water pump is switched on. From 7 to 10 pm energy is necessary for street lighting. Considering that electricity should serve both to meet basic needs and to improve the economic income of the population, and since this community has an incipient ecological tourism, the consumption of cabins for visitors is added.

Figure 1 shows the community load profile of a typical day based on the above-described behavior. The annual average energy is $89.91 \mathrm{kWh} /$ day, and the average demand is $3.75 \mathrm{~kW}$. The maximum load showed in this Figure is $13.98 \mathrm{~kW}$. However, to make a more realistic simulation, HOMER allows the use of random day-to-day and Timestep factors to the loads. Using $10 \%$ and $20 \%$ respectively as these variables, the peak load estimated by HOMER is $23.70 \mathrm{~kW}$.

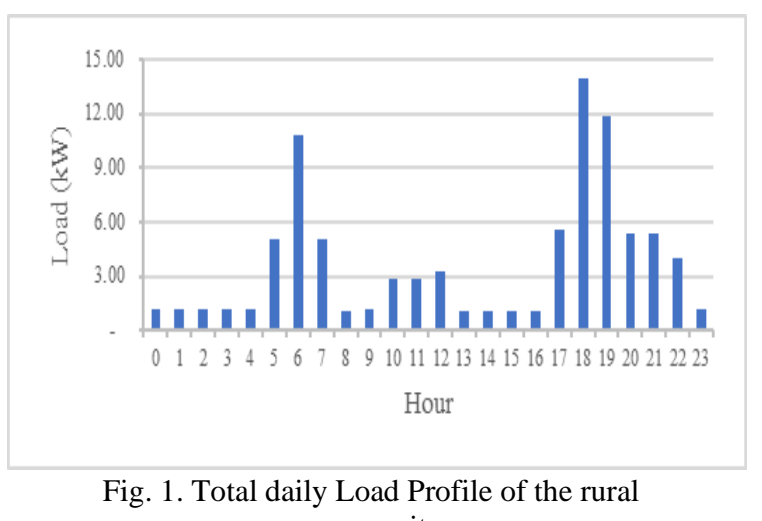
community

\subsection{Solar energy resource assessment}

Figure 2 shows the solar radiation and clearness index at the selected location of $1^{\circ} 32^{\prime} \mathrm{S}$ and $75^{\circ} 35^{\prime} \mathrm{W}$. These values were taken from the NASA Website [23]. The average solar radiation on 22 years of available data is $4.37 \mathrm{kWh} / \mathrm{m}^{2} /$ day.

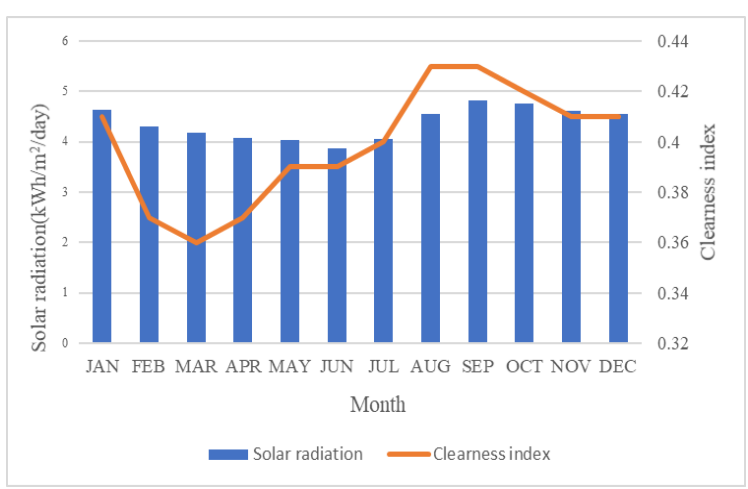

Fig. 2. Average annual solar radiation and Clearness Index at the community 
The temperature in the study place is shown in Figure 3, the recorded values are ideal to have less losses due to the effect of temperature on the photovoltaic cells, being in a tropical area the data are similar. The annual average temperature is 24.5 ${ }^{\circ} \mathrm{C}$.

All these parameters are inputs for the calculation of a solar-based module, which, according to this information, may be a solid alternative.

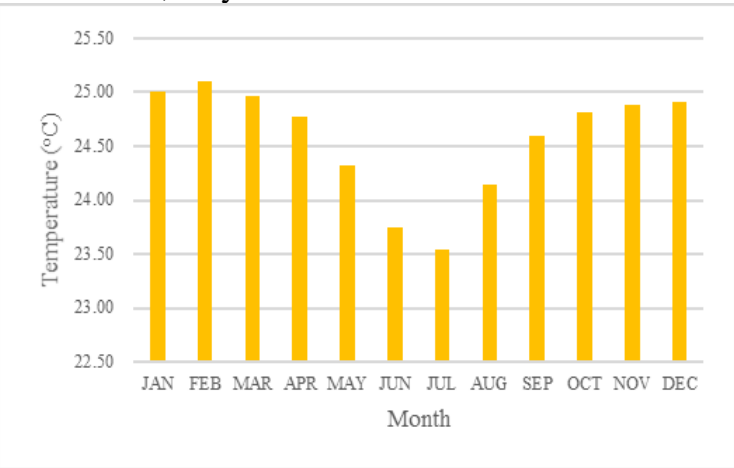

Fig. 3. Average ambient temperature at the community

\subsection{Wind resource assessment}

With an average wind speed of less than $0.7 \mathrm{~m} / \mathrm{s}$ according to NASA's website, it is considered that the wind resources of the area are not sufficient for its use.

\subsection{Proposed hybrid renewable system modelling}

The proposed system is modeled in HOMER as shown on Figure 4. Solar PV modules are connected to a DC bus. A battery attached to the same bus offsets the intermittence of this resource, playing a role of storage unit. The load and a DG are connected to the AC bus. A converter makes the transition from $\mathrm{AC}$ to DC.

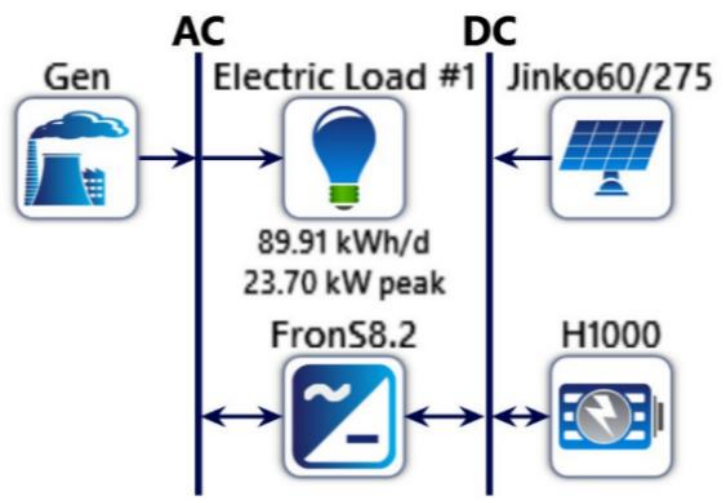

Fig. 4. Proposed hybrid model

\subsubsection{PV modules}

The selected PV panel model is the Eagle 60P of the manufacturer Jinko with a maximum power of $275 \mathrm{Wp}$ at standard test conditions (STC). Both capital and replacement costs are taken as $\$ 1.000$ per $\mathrm{kW}$ (24), based on an average full replacement after a 25 years period of use. The operation and maintenance $(\mathrm{O} \& \mathrm{M})$ cost is assumed to be $\$ 10 /$ year per $\mathrm{kW}$, based on a three times per year schedule of maintenance using mainly community workforce for simple cleaning and adjustment tasks.

\subsubsection{Diesel Generator}

An auto-size generator is considered. The initial capital and replacement costs are considered as $\$ 350 / \mathrm{kW}(25)$. The O\&M costs is assumed as $\$ 0.03$ per $\mathrm{kWh}$. The diesel fuel price is considered as $\$ 0.79$ per liter.

\subsubsection{Battery}

The selected battery is a Hoppecke model 10 OPzS with a nominal capacity of $2.39 \mathrm{kWh} / 2 \mathrm{~V}$. Capital and replacement costs are taken as $\$ 500$ per unit (26), O\&M of $\$ 10$ per year and expected throughput of $3,381.20 \mathrm{kWh}$.

\subsubsection{Converter}

The proposed converter is a Fronius Symo 8.2 with initial cost of $\$ 350$ per $\mathrm{kW}$. The replacement is assumed to be the same cost and the O\&M is $\$ 10$ per year.

\section{RESULTS AND DISCUSSION}

\subsection{Optimization results}

HOMER finds the optimal combination, capacities and operation modes of the selected components of the simulated microgrid that fulfills the load at the lowest cost. HOMER performs the simulation of thousands of possible systems and verifies their feasibility by performing energy balances. The cost throughout the life cycle of the system is calculated and presented in ascending order, showing the results of the optimization.

Table 1 shows the Total Net Present Cost (NPC) and the LCOE for feasible systems, with the respective optimized sizing of their components. The most economical system is composed of PV modules of $22.9 \mathrm{~kW}, 37$ batteries and a DG of $27 \mathrm{~kW}$. With this configuration an NPC of $\$ 152,502$ and a LCOE of $\$ 0.359 / \mathrm{kWh}$ are obtained. The energy production is $44,127 \mathrm{kWh}$, distributed between PV panels and DG as shown in Figure 5.

Table 1. Optimization Results

\begin{tabular}{llccccc}
\hline Rank & System & $\begin{array}{c}\text { PV } \\
(\mathrm{kW})\end{array}$ & $\begin{array}{c}\text { BATT } \\
\text { Qty. }\end{array}$ & $\begin{array}{c}\text { DG } \\
(\mathrm{kW})\end{array}$ & $\begin{array}{c}\text { NPC } \\
(\$)\end{array}$ & $\begin{array}{c}\text { LCOE } \\
(\$)\end{array}$ \\
\hline 1 & PV/DG/BATT & 22.9 & 37 & 27 & 152,502 & 0.359 \\
\hline 2 & PV/BATT & 48.4 & 98 & & 168,711 & 0.403 \\
\hline 3 & DG/BATT & & 24 & 27 & 202,364 & 0.477 \\
\hline 4 & PV/DG & 41.3 & & 27 & 356,876 & 0.841 \\
\hline 5 & DG & & 37 & 27 & 413,170 & 0.974 \\
\hline
\end{tabular}

Table 2 shows the costs of the components of the PV/DG/BATT system. The higher costs come from the initial investments in batteries and PV panels with $\$ 22.200$ and $\$ 22.917$, respectively. The highest replacement costs are those of the batteries with $\$ 20,273$. The generator has significant O\&M costs 
$(\$ 20,273)$, but the biggest expenses are fuel costs of $\$ 45,830$, representing $30 \%$ of the total cost of the project.

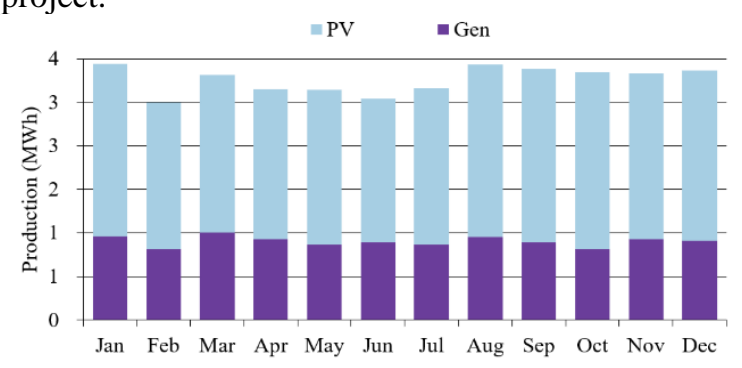

Fig. 5. Energy production of the PV/DG system

Table 2. INet present cost detail of the PV/DG/BATT

\begin{tabular}{lccccc}
\hline Cost (\$) & PV & DG & BATT & Fronius & $\begin{array}{c}\text { Total } \\
\text { System }\end{array}$ \\
\hline Capital & 22,917 & 9450 & 22,200 & 3287 & 57,855 \\
\hline Replacement & 0 & 7413 & 20,273 & 2904 & 30,591 \\
\hline O\&M & 2962 & 13,612 & 4783 & 1214 & 22,572 \\
\hline Fuel & 0 & 45,830 & 0 & 0 & 45,830 \\
\hline Salvage & 0 & -1886 & -2068 & -393 & -4348 \\
\hline Total & 25,880 & 74,420 & 45,188 & 7012 & 152,501 \\
\hline
\end{tabular}

The second-best option in Table 1 is PV/BATT. With this configuration the LCOE is $0.403 \$ / \mathrm{kWh}$, and the NPC is $\$ 168,711$. Table 3 shows the breakdown of costs. The investments in capital and replacement are $\$ 114,272$ and $\$ 34,464$, respectively, which are significantly higher than those of alternative $1(\$ 57,815$ and $\$ 30,591)$ but are balanced at the final value of the system by having fuel costs of $\$ 0$.

Table 3. Net present cost detail of the PV/BATT system

\begin{tabular}{lcccc}
\hline \multicolumn{1}{c}{ Cost (\$) } & PV & BATT & Fronius & $\begin{array}{c}\text { Total } \\
\text { System }\end{array}$ \\
\hline Capital & 48,440 & 58,800 & 7031 & 114,272 \\
\hline Replacement & 0 & 28,251 & 6212 & 34,464 \\
\hline O\&M & 6262 & 12,668 & 2597 & 21,528 \\
\hline Fuel & 0 & 0 & 0 & 0 \\
\hline Salvage & 0 & -711 & -842 & -1553 \\
\hline Total & 54,702 & 99,009 & 14,999 & 168,711 \\
\hline
\end{tabular}

The next systems in Table 1 don't use solar resources and have much higher costs due to the intense use of DG and consequent high fuel expenditure. It is observed that, using only the components currently available to the community (PV/DG), would have a configuration similar to the fourth in the table, obtaining an LCOE of 0.841 $\$ / \mathrm{kWh}$, which is more than double the proposed optimized solution.

\subsection{Sensitivity Analysis}

In the previous section the optimized system according to the cost parameters, natural resources and load conditions detailed previously was identified. However, some of these values are variable and entail a certain degree of uncertainty, such as the costs of batteries and PV panels, the radiation of the sun, or the consumption patterns of the population.

It is then necessary to subject the selected system to a sensitivity analysis. This analysis allows stakeholders to make smarter decisions by evaluating the response of the system to the variability of the inputs.

From the analysis carried out, the following significant variables have been identified:

- The diesel price, which is subjected to the influence of the international market, political decisions, and availability of transportation to isolated communities. For this analysis it is being considered that it can vary from $\$ 0.66$ to $\$ 0.94$ per liter.

- The cost of technologic components (PV panels, converters, and BATT from $100 \%$ to $50 \%$ ).

- Solar radiation (3.5 to $4.8 \mathrm{kWh} / \mathrm{m}^{2} /$ day).

- The community's demand (45 to $145 \mathrm{kWh} /$ day).

The spider plot shown in Fig. 6 allows to quickly visualize the effects of the above-mentioned variables on costs. As expected, a higher solar radiation reduces the cost of energy. An increase in demand above the initial value also reduces the LCOE. Fuel prices below the current reference decrease the cost, but above values have no effect, which indicates that on these conditions, the dispatch of DG can be restricted. It is observed that the parameter that has the greatest influence in the LCOE is the price of the technological components. It is the steepest line of the project; therefore, it should receive the greatest attention from investors.

The optimal system plot shown on Fig. 7 graphically outlines under which combination of values of diesel cost and demand, the PV/DG/BATT or PV/BATT are optimal. It is clearly visible that the first option is suitable for high values of demand and low cost of diesel. The PV/BATT system is optimal for low demand values and expected higher fuel costs.

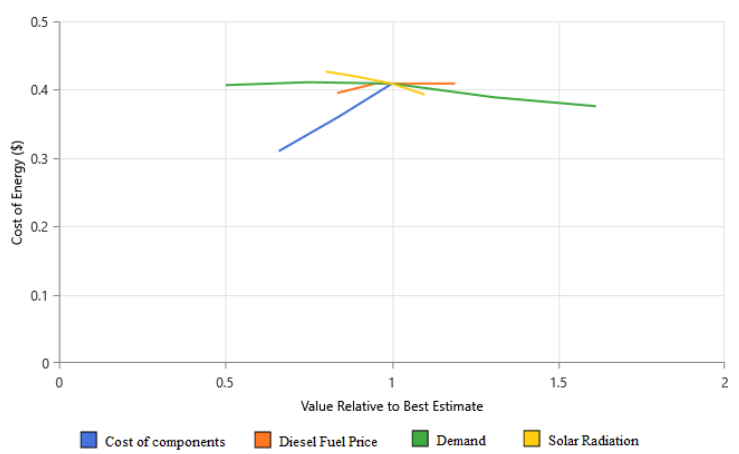

Fig. 6. Spider Plot of the systems

Fig. 8 establishes the value of the fuel cost that, according to optimization results, it is more effective to stop using DG. This value is $\$ 0.83$ per liter, higher values imply not using the DG. Also, there is a jump of LCOE from 0.380 to $0.403 \$ / \mathrm{kWh}$ due to this transition. 
Fig. 9 shows the combination of component costs and solar radiation. Therefore, it allows to establish that the system without GD is optimal if component prices keep the current lowering trend.

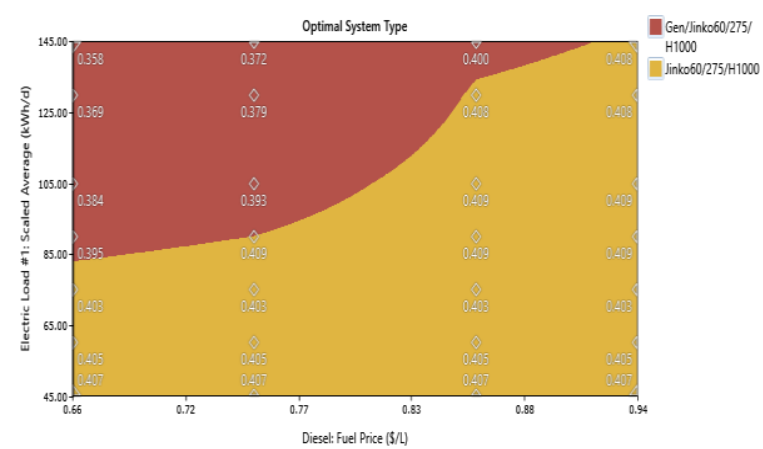

Fig. 7. Optimal system plot according to demand and diesel prices

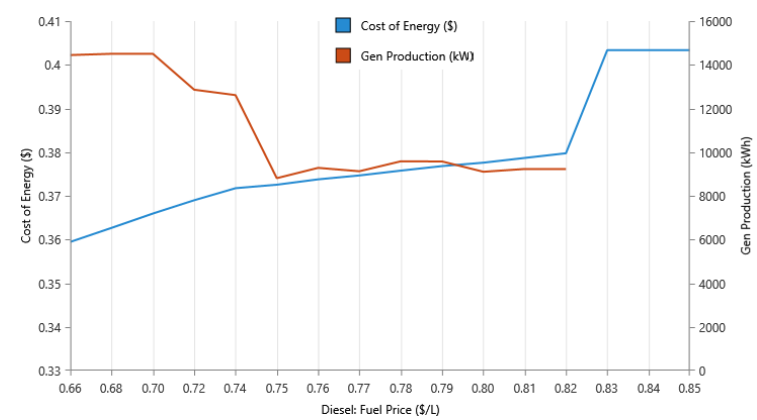

Fig. 8. LCOE and DG Production vs. Diesel price

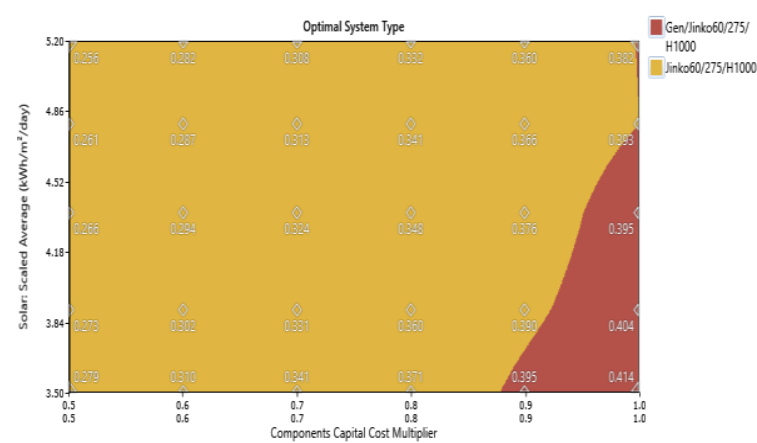

Fig. 9. Optimal system according to Solar radiation and Components costs

The surface plots show the LCOE variation in relation with the variables indicated in the axes, in such a way that, as it increases its value, it changes tones gradually from blue to red.

The blue zone in Fig. 10 indicates an LCOE of $0.358 \$ / \mathrm{kWh}$. This value increases rapidly as demand decreases, but in contrast, if the value of diesel is increased, there are not such sudden changes. This indicates that the system will be more efficient at higher load levels. Also, if demand is low or diesel prices remain high, the LCOE can reach values close to $0.409 \$ / \mathrm{kWh}$.

Sensitivity analysis also allows the optimization results to be applied to more than one facility, without having to run new studies for other locations. Fig. 11 shows that the LCOE can be kept low even with high fuel costs if solar radiation is maintained at high levels. In this way, similar projects can apply the same system, without having to repeat simulations if the appropriate weather conditions are met.

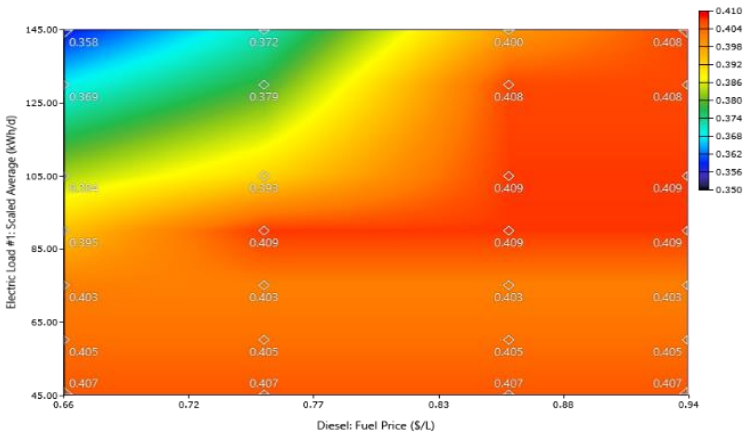

Fig. 10. Surface Plot: Demand and Fuel price, superimposed: LCOE

The almost horizontal stripes shown in Fig. 12 indicate that the LCOE depends more on the costs of technological components than on demand. This trend remains uniform for almost all demand values, except for the highest ones.

In contrast, the effects on the LCOE of solar radiation causes significant changes in costs, as does demand, as shown in Fig. 13.

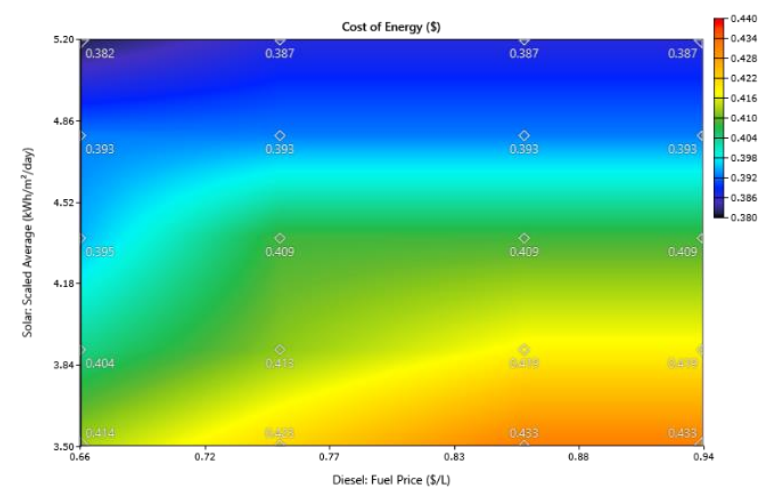

Fig. 11. Surface Plot: Solar radiation and Fuel price, superimposed: LCOE

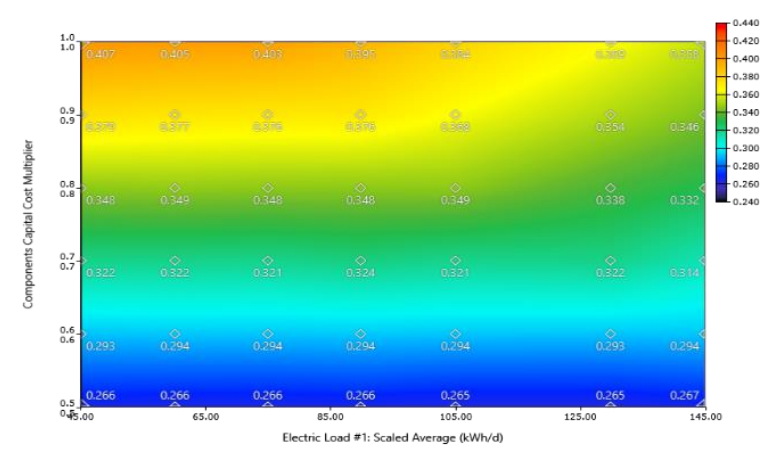

Fig. 12. Surface plot: Component costs and Demand, superimposed: LCOE

Fig. 14 shows that the influence of the costs of the technological components on the LCOE is much greater than that of solar radiation, since small changes in the prices of the components cause a substantial increase in the costs of the project. 


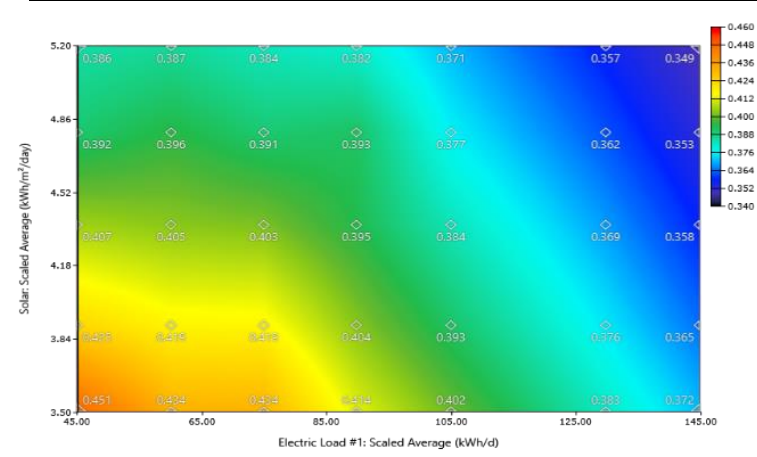

Fig. 13. Surface plot: Solar radiation and Demand, superimposed: LCOE

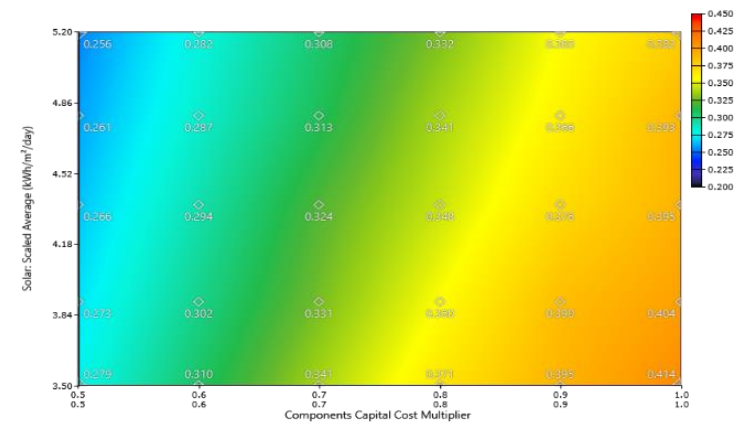

Fig. 14. Surface plot: Solar radiation and component costs, superimposed: LCOE

\section{CONCLUSION}

This study assessed the feasibility of a hybrid offgrid PV/DG/BATT system for the electrification of a rural community using a case study in Bameno, Ecuador. A sensitivity analysis was performed to analyze the influence that the demand, solar radiation and costs of fuel and technological components have on the LCOE. The results showed that the optimal configuration for the off-grid power system is composed by $23 \mathrm{~kW}$ of PV modules, one DG $27 \mathrm{~kW}, 88.4 \mathrm{kWh}$ storage batteries and $9.4 \mathrm{~kW}$ converter. This system can produce $44.127 \mathrm{kWh}$ a year with a LCOE of $0.359 \$ / \mathrm{kWh}$.

The sensitivity analysis revealed that for fuel prices above $\$ 0.83$ per liter, the optimized power system alternative changes from PV/DG/BATT to PV/BATT. It was also determined that the LCOE is highly sensitive to the costs of the technological components. To a lesser extent, this index is affected by the changes on solar radiation. Finally, it was found that the LCOE improves with higher demand values.

Author contributions: research concept and design, J.C.L, P.Z.P.; Collection and/or assembly of data, J.C.L, P.Z.P.; Data analysis and interpretation, J.C.L, P.Z.P.; Writing the article, J.C.L, P.Z.P.; Critical revision of the article, J.C.L, P.Z.P.; Final approval of the article, J.C.L, P.Z.P.

Declaration of competing interest: The authors declare that they have no known competing financial interests or personal relationships that could have appeared to influence the work reported in this paper.

\section{REFERENCES}

1. Fujii T, Shonchoy AS, Xu S. Impact of electrification on children's nutritional status in rural bangladesh. World Dev. 2018;102:315-30. https://doi.org/10.1016/j.worlddev.2017.07.016.

2. Kumar S, Rauniyar G. The impact of rural electrification on income and education: Evidence from Bhutan. Rev Dev Econ. 2018;22(3):1146-65. https://doi.org/10.1111/rode.12378

3. International Energy Agency. World Energy Outlook 2020 - Analysis - IEA. 2020.

https://www.iea.org/reports/sdg7-data-andprojections/access-to-electricity\#abstract

4. Wilmsmeier G, Jaimurzina A, Montiel D. Eficiencia energética y movilidad fluvial: soluciones sostenibles para la Amazonía. Boletín FAL. 2017;353(1):11. https://www.mme.gov.br/.

5. Feng W, Jin M, Liu X, Bao Y, Marnay C, Yao C, et al. A review of microgrid development in the United States - A decade of progress on policies, demonstrations, controls, and software tools. Appl Energy. 2018;228:1656-68. https://doi.org/10.1016/j.apenergy.2018.06.096.

6. Come Zebra EI, van der Windt HJ, Nhumaio G, Faaij APC. A review of hybrid renewable energy systems in mini-grids for off-grid electrification in developing countries. Renew Sustain Energy Rev. 2021;144. https://doi.org/10.1016/j.rser.2021.111036.

7. Li J, Liu P, Li Z. Optimal design and techno-economic analysis of a solar-wind-biomass off-grid hybrid power system for remote rural electrification: A case study of west China. Energy. 2020;208:118387. https://doi.org/10.1016/j.energy.2020.118387.

8. Ur Rehman S, Rehman S, Qazi MU, Shoaib M, Lashin A. Feasibility study of hybrid energy system for offgrid rural electrification in southern Pakistan. Energy Explor Exploit. 2016;34(3):468-82. https://doi.org/10.1177/0144598716630176

9. Lotfi H, Khodaei A. Levelized cost of energy calculations for microgrids. IEEE Power Energy Soc Gen Meet. 2016;2016-Novem:1-5. https://doi.org/10.1109/PESGM.2016.7741379.

10. Fox J, Okten G, Uzunoglu B. Global sensitivity analysis for power systems via quasi-monte carlo methods. 2019 4th Int Conf Syst Reliab Safety, ICSRS 2019. 2019;446-51.

https://doi.org/10.1109/ICSRS48664.2019.8987666.

11. Mohammadi M, Hosseinian SH, Gharehpetian GB. GA-based optimal sizing of microgrid and DG units under pool and hybrid electricity markets. Int J Electr Power Energy Syst. 2012;35(1):83-92.

http://dx.doi.org/10.1016/j.ijepes.2011.09.015.

12. Toopshekan A, Yousefi H, Astaraei FR. Technical, economic, and performance analysis of a hybrid energy system using a novel dispatch strategy. Energy. 2020;213:118850.

https://doi.org/10.1016/j.energy.2020.118850.

13. Arévalo P, Benavides D, Lata-García J, Jurado F. Techno-economic evaluation of renewable energy systems combining PV-WT-HKT sources: Effects of energy management under Ecuadorian conditions. Int Trans Electr Energy Syst. 2020;30(10):1-26. https://doi.org/10.1002/2050-7038.12567.

14. Halabi LM, Mekhilef S, Olatomiwa L, Hazelton J. Performance analysis of hybrid PV/diesel/battery system using HOMER: A case study Sabah, Malaysia. 
Energy Convers Manag. 2017;144:322-39. http://dx.doi.org/10.1016/j.enconman.2017.04.070.

15. Cristian H, Bizon N, Alexandru B. Design of hybrid power systems using homer simulator for different renewable energy sources. Proc 9th Int Conf Electron Comput Artif Intell ECAI 2017. 2017;1-7.

16. Pawar N, Nema P. Techno-Economic Performance Analysis of Grid Connected PV Solar Power Generation System Using HOMER Software. 2018 IEEE Int Conf Comput Intell Comput Res ICCIC 2018. 2018;

17. Shamachurn H. Optimization of an off-grid domestic Hybrid Energy System in suburban Paris using iHOGA software. Renew Energy Focus. 2021. https://doi.org/10.1016/j.ref.2021.02.004.

18. Lata-Garcia J, Jurado-Melguizo F, Sanchez-Sainz H, Reyes-Lopez C, Fernandez-Ramirez L. Optimal sizing hydrokinetic-photovoltaic system for electricity generation in a protected wildlife area of Ecuador. Turkish J Electr Eng Comput Sci. 2018;26(2):110314.

19. Lata-Garcìa J, Reyes-Lopez C, Jurado F, FernándezRamírez LM, Sanchez H. Sizing optimization of a small hydro/photovoltaic hybrid system for electricity generation in Santay Island, Ecuador by two methods. 2017 Chil Conf Electr Electron Eng Inf Commun Technol CHILECON 2017 - Proc. 2017;2017Janua:1-6.

20. López-González A, Domenech B, Gómez-Hernández D, Ferrer-Martí L. Renewable microgrid projects for autonomous small-scale electrification in Andean countries. Renew Sustain Energy Rev [Internet]. 2017;79:1255-65. http://dx.doi.org/10.1016/j.rser.2017.05.203.

21. GAD(Cononaco). Actualizacion del PDOT de la parroquia de Cononaco. 2020.

22. Enrique L, Villafuerte M. Elaboración y evaluación de modelos energéticos sostenibles en entornos rurales aislados de la Amazonía del Ecuador / Luis Enrique Manzano Villafuerte. 2021.

23. Data Access Viewer. https://power.larc.nasa.gov/data-access-viewer/

24. IRENA Renewable Cost Database. Renewable Power Generation Costs in 2020. International Renewable Energy Agency. 2020. https://www.irena.org//media/Files/IRENA/Agency/

Publication/2018/Jan/IRENA_2017_Power_Costs_20 18.pdf

25. Pintulac. Tu amigo experto en acabados para construcción y maquinaria. Pintulac 2021 https://www.pintulac.com.ec/

26. Autosolar Energy Solutions S.L.U. Autosolar La Tienda de la Energía Solar. 2021. https://autosolar.es/

Received 2021-11-10

Accepted 2022-01-03

Available online 2022-01-17
Pazmiño-Zapatier PEDRO

graduated in Electrical Engineering at Escuela Politécnica del Litoral, and is currently pursuing Master's degree in Electrical Power Systems at Universidad Politécnica Salesiana, Guayaquil, Ecuador

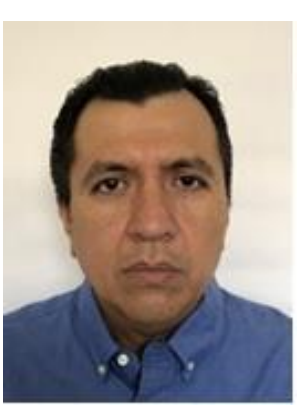

Lata-García JUAN received PHD degree from Universidad de Jaén, España and is with the Research Group in Industrial Processes (GIPI), Universidad Politécnica Salesiana, Guayaquil, Ecuador 